Relations industrielles

Industrial Relations

\title{
Paid Vacations in Canada
}

Volume 13, numéro 1, janvier 1958

URI : https://id.erudit.org/iderudit/1022475ar

DOI : https://doi.org/10.7202/1022475ar

Aller au sommaire du numéro

Éditeur(s)

Département des relations industrielles de l’Université Laval

ISSN

0034-379X (imprimé)

1703-8138 (numérique)

Découvrir la revue

Citer ce document

(1958). Paid Vacations in Canada. Relations industrielles / Industrial Relations, 13(1), 104-104. https://doi.org/10.7202/1022475ar

Tous droits réservés (C Département des relations industrielles de l’Université Laval, 1958
Ce document est protégé par la loi sur le droit d'auteur. L'utilisation des services d'Érudit (y compris la reproduction) est assujettie à sa politique d'utilisation que vous pouvez consulter en ligne.

https://apropos.erudit.org/fr/usagers/politique-dutilisation/ 


\section{PAID VACATIONS IN CANADA}

Paid vacations for Canadian workers are more widespread, of longer duration, and require shorter relative qualifying periods than ever before in Canada's history, according to information released October 1st, 1957 by Hon. Michael Starr, Federal Minister of Labour.

This information was brought out as a result of the 1956 annual survey of working conditions conducted by the Labour Department's Economics and Research Branch. The survey covered firms in most branches of industry with total employment of more than $1,600,000$ workers. Of this total about 75 per cent were nonoffice and 25 per cent office employees.

(Further details are contained in the September issue of the Labour Gazette.?

The most notable developments in regard to vacation practices in Canada have been, first of all, the growth in their incidence, particularly for non-office workers; secondly, the extension of annual vacations to two and three weeks per year, in some cases to four weeks; and thirdly, the reduction of service requirements for entitlement to vacations of various lengths. Also a feature, is the growing similarity. in most industrial groups, in vacations for non-office and office workers.

In 1949, 97 per cent of office workers in manufacturing had paid vacations of two weeks while only 81 per cent of non-office employees had two weeks. However, in 1956 the corresponding percentages were 99 and 92 respectively. Similarly, in 1949, 42 per cent of office workers could become eligible for vacations of three weeks, compared with only 30 per cent of non-office workers, while in 1956 these figures had become 72 and 63 per cent respectively. In both years the granting of vacations was subject to qualifying service periods of varying lengths.

The following table gives percentages of employees in establishments reporting 2,3 and 4 week vacations. It illustrates the present comparative similarity of treatment of non-office and office employees:

\begin{tabular}{|c|c|c|c|c|c|c|}
\hline & $\begin{array}{c}2 \text { Wee } \\
\text { Non-Office } \\
\%\end{array}$ & $\begin{array}{l}\text { Office } \\
\%\end{array}$ & $\begin{array}{c}3 \text { Wee } \\
\text { Non-Office } \\
\%\end{array}$ & $\begin{array}{c}\text { Office } \\
\%\end{array}$ & $\begin{array}{c}4 \text { Wee } \\
\text { Non-Office } \\
\%\end{array}$ & $\begin{array}{c}\text { Office } \\
\%\end{array}$ \\
\hline Manufacturing & 92 & 99 & 63 & 72 & 10 & 13 \\
\hline Coal Mining & 99 & 99 & $\mathbf{v}$ & $\mathrm{v}$ & $\mathrm{v}$ & $\mathrm{v}$ \\
\hline Metal Mining & 91 & 91 & 48 & 56 & 25 & 40 \\
\hline Steam Railways & 100 & 100 & 100 & 100 & $\mathrm{v}$ & $\mathrm{v}$ \\
\hline $\begin{array}{l}\text { Urban \& Suburban Pass- } \\
\text { enger Transportation }\end{array}$ & 99 & 99 & 97 & 99 & 33 & 23 \\
\hline Truck Transportation & 95 & 98 & 34 & 31 & v & $\mathrm{v}$ \\
\hline Public Utilities & 94 & 97 & 96 & 97 & 52 & 67 \\
\hline Wholesale Trade & 96 & 99 & 61 & 78 & 16 & 22 \\
\hline Retail Trade & 98 & 99 & 66 & 63 & 41 & 57 \\
\hline Laundries & 65 & 82 & 13 & 1 & $\mathrm{v}$ & $\mathbf{v}$ \\
\hline Hotels & 93 & 94 & 35 & 27 & $\mathrm{v}$ & $\mathbf{v}$ \\
\hline Restaurants & 72 & 81 & 35 & 42 & 20 & 31 \\
\hline
\end{tabular}

v Less than 1 per cent

It will be noted from the foregoing table that as a general rule the proportion of office workers is higher than for non-office, although in a few cases in the " 3 -weeks" column the reverse occurs. 